\title{
Improvement of Fifth Grade Students' Mathematical Reasoning and Learning Activity with the Implementation of Problem Solving Learning Model
}

\author{
Efry Yenny ${ }^{1}$, Ahmad Fauzan ${ }^{1}$, Yanti Fitria ${ }^{1 *}$ \\ ${ }^{1}$ Faculty of Education, Padang State University, Padang, Indonesia \\ *yanti fitria@fip.unp.ac.id \\ Received: July $31^{\text {st }}, 2020$ \\ Revised: August $03^{\text {th }}, 2020$ \\ Accepted: August $05^{\text {th }}, 2020$
}

\begin{abstract}
This research is background by a low mathematical ability of students' reasoning and learning activities in mathematics. Therefore, the aim of this research is to increase students' reasoning and learning activities with the implementation of problem solving learning model. Type of research is classroom action research which have a cycle model consist of four components, namely planning, action, observation and reflection. This research conducted in two cycles that consisting of four meetings. At each cycle student activities during the learning process were observed, and at the end of each cycle a test of learning outcomes was given. The research is carried out with 30 fifth grade students from a public elementary school in semester 2 of the 2019/2020 school year. The instruments used were observation, and field notes, interviews and test results. The data obtained in the research were analyzed using qualitative analysis, analyzing the collection of data until all data has been collected. The data is reduced based on the problem under study, followed by the presentation of the data and finally the conclusion or verification. The results show that fifth grade students' mathematicalreasoning and learning activities increase after the implementation of problem solving learning model.
\end{abstract}

Keywords: learning activities; mathematics; problem solving; reasoning

\section{INTRODUCTION}

Learning mathematics is one of the learning processes that students go through in elementary school. Mathematics is one of the basic sciences and is also used directly in everyday life (Mulyati, Firman, \& Fitria, 2016). Mathematics has an important position, because it is a basic science that is the basis of the development of science and technology. The main purpose of learning mathematics in schools is that students have sufficient mathematical abilities to continue their education to a higher level and to solve problems in everyday life (Fauzan \& Yerizon, 2013).

According to Fitra (2017a), learning is basically a process of interaction and communication between teacher and students. Learning mathematics allows the students to acquire the skills to analyse various problems or situations, 
anticipate, plan, make decisions, and solve problems According to Depdiknas (2006:416) "Mathematics needs to be given to all students starting from elementary school to equip students with the ability to think logically, analytically, systematically, critically and creatively, as well as the ability to work together". The reform movements in mathematics which underscore a move away from teaching mathematics as a series of abstract procedures, provides an impetus for contexts to enhance understanding of mathematical problems (Widjaja, Dolk, \& Fauzabn, 2010:168).

One of the abilities that students must develop based on the goals of mathematics learning is reasoning ability. Reasoning ability is the ability to use mathematical rules or logic to obtain a correct conclusion. Reasoning processes need to be developed in mathematics learning, as stated in the learning objectives of mathematics (Depdiknas 2006). Depdiknas (2006) states that "mathematical material and mathematical reasoning are two things that are related and cannot be separated, because mathematical material is understood through reasoning and reasoning is trained through mathematical learning". Students who are less skilled at calculating and reasoning will have difficulties; this difficulty makes children feel bored and less interested in mathematics. Sari, Rakimahwati, \& Fitria (2019) argued that certain materials in mathematics subjects are difficult for students to understand if they are delivered only orally. With mathematical reasoning abilities help students think systematically, able to solve mathematical problems in everyday life. In addition, students are also able to apply mathematics to other fields of science.

National Council of Mathematic Teachers (NTCM) revealed that there are six standard competencies that can be developed in mathematics, namely the ability of problem solving, reasoning ability, communication skills, ability to connection, ability to representation, and the ability to disposition. Based on the mathematical objectives and the six standard competencies, through learning mathematics can develop a variety of abilities and potential students to become better, more reasoning, creative, innovative and think logically and systematically.

Mathematical reasoning is a think process carried out in a way to draw conclusions. The ability to reason makes students able to solve problems in their lives, inside and outside of school. Mathematical reasoning is a process of thinking to determine whether a mathematical argument is true or false and is also used to construct a new mathematical argument (Putra, Zulkadri, \& Hartono, 2016).

The initial results of observations in class $\mathrm{V}$ in mathematics learning, students have low reasoning abilities From the average results of daily tests obtained, it was seen that the percentage of students under the minimum completeness criteria ( $\leq 75)$ was quite large namely $57.14 \%$ (daily tests 1 / UH 1), 66.67\% (daily 
tests 2 ), and $61,90 \%$ (daily test 3 ). The material learned is about the KPK and FPB (UH 1), integer count operations (UH $2)$, time measurement ( $\mathrm{UH} 3)$.

According to Fitria et al (2013), the main problem in learning formal education is the low absorptive capacity of learning or learners. Student activities in the learning process are also low, in addition to their low reasoning abilities. Students tend to be passive and do not want to ask questions when actually they have not fully understood the material. When given practice questions most students do not want to try hard to solve them. They just wait for answers from the teacher or imitate answers made by classmates. This results in a learning atmosphere that is not conducive because students are reluctant to be actively involved in the learning process. Oktriani, Fauzan, \& Ellizar (2018) state that many factors have influence the low activity and critical thinking ability of learners in a learning process, one of them is the absence of learning model and media used by teacher in class. This low student activity because teacher always using a monotonous learning model, so students are accustomed to accepting it from the teacher without wanting to try and not actively involved in the learning process. must be able to teach students to use various learning resources with (Murtiani, Fauzan, \& Ratnawulan, 2012).

Activities are important in learning because learning is in principle a change in behaviour. The desire to want to learn mathematics can be seen from learning activities. Sardiman (1986) says "There is no learning if there is no activity". So that the atmosphere of learning is conducive and learning more meaningful students are expected to be actively involved in the learning process. Involvement is the level which students actively participate in learning activities, resulting in increased learning and interest. Eggen (2012) says that involvement is important to place students in active roles, especially cognitively.

Seeing the above facts, the learning process cannot be said to be good or there is still not enough effort to improve it. The good learning process must be able to give an impression and meaning to students and the learning is fun for students according to their development needs, for that we need a learning model that can improve students' abilities in learning mathematics.

Several learning approaches and models have been developed by researchers and education practitioners to improve reasoning abilities and other higher-order thinking skills. Mujis and Reynolds (2008: 186) revealed four approaches to improve thinking skills, namely problem solving, metacognitive, open-ended and active approaches, and formal thinking approaches. Meanwhile, Rusman (2010: 141-142) Classifying several learning models such as inductive thinking, scientific inquiry, concept discovery, and cognitive growth in a cluster of information processing models. This model clump is generally based on Piaget's cognitive theory with an 
orientation to build students ability to collect and process information, solve problems and find concepts.

The researcher suggests to the fifth class teacher to improve the mathematics learning process by using an appropriate learning model. In addition to learning strategies, motivation factors are very important in determining the effectiveness of learning (Anastasha, Fitria, \& Irdamurni, 2018). Several alternative learning models suggested, class V teacher choose the Problem Solving model to use. Problem Solving Model is a model that can develop students thinking skills and practice their ability to face and solve problems. According to Wina (2008:214) "problem solving learning model is a series of learning activities that emphasize the process of solving problems scientifically, from searching for data to drawing conclusions".

\section{METHODS}

This type of research is classroom action research. This cycle model has four components, namely planning, action, observation and reflection. This research was conducted in two cycles, the first and second cycles. At the end of each cycle is carried out the learning outcomes test. At each cycle is carried out observations of student activities during the learning process. This class action research was carried out in a public elementary school in West Sumatera Province, Indonesia. The subjects in this study were fifth grade students, registered in semester 2 of the school year 2019/2020, with the sum are 30 students. The instruments used in this study are observation, and field notes, interviews and test results. The data obtained in the research is analysed using qualitative analysis, namely the analysis of the data began by analyse the data collection until all data was collected. The data is reduced based on the problem under research, followed by the presentation of the data and finally the conclusion or verification.

\section{RESULTS}

\section{a. Cycle I}

In accordance with the formulation of the problem the results of the preliminary study the researcher together with the teacher makes an action plan to be carried out. The action was in the form of learning mathematics by using problem solving models. The action is in the form of learning mathematics by using problem solving models. This activity begins by formulating a mathematics learning action plan based on a problem solving model that is with the following activities: 1) Establishing a schedule during research, 2) Assessing KTSP Elementary School Mathematics, class V textbooks and other relevant mathematics books, 3) Arranging the action plan in the form of a lesson plan This includes: competency standards, basic competencies, indicators, theory, models, learning activities, media / resources, evaluation / assessment, 4) Preparing the media needed in the learning process, 5) Preparing instruments for observing students 
worksheet and tools evaluation to monitor teacher and student activities, 6) Arranging observation sheets to record student activities, and 7) Discussing with class teacher about the procedures for collecting data in observing when the activities are carried out, so that there are no irregularities in data collection.

The learning process gives the results of students' reasoning abilities, which obtained an average achievement with a value of 70.17 . More clearly can be seen in figure 1 :

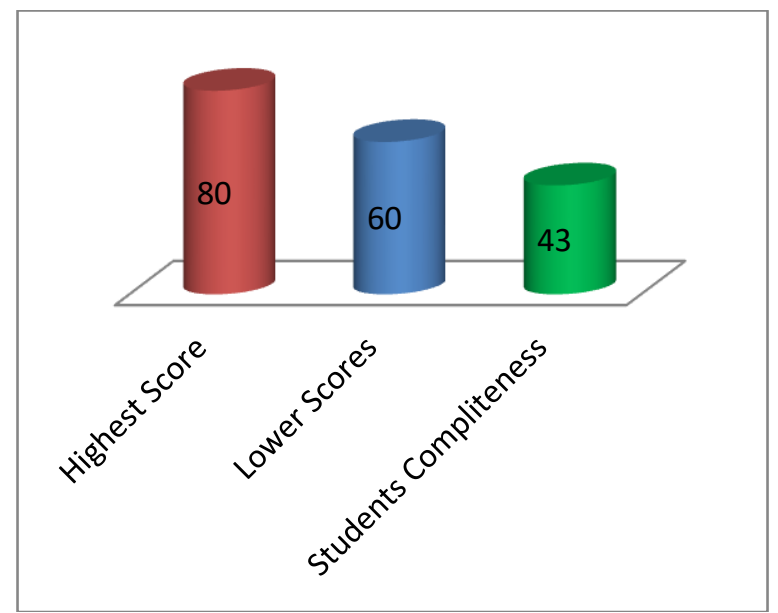

Figure 1. Results obtain of students reasoning capabilities in cycle II

Based on figure it can be concluded that the reasoning ability of students in learning mathematics can be the highest value of 80 and the lowest value of 60 . Then from 30 students, only 13 students completed the study with a percentage of $43.33 \%$, the remaining 17 students were not yet finished. This is because in the first cycle the application of the problem solving model has not been fully implemented. There are still students who are not serious and are constrained in applying the model. In addition, student learning activities also still need to be increased again. This can be seen in figure 2 :

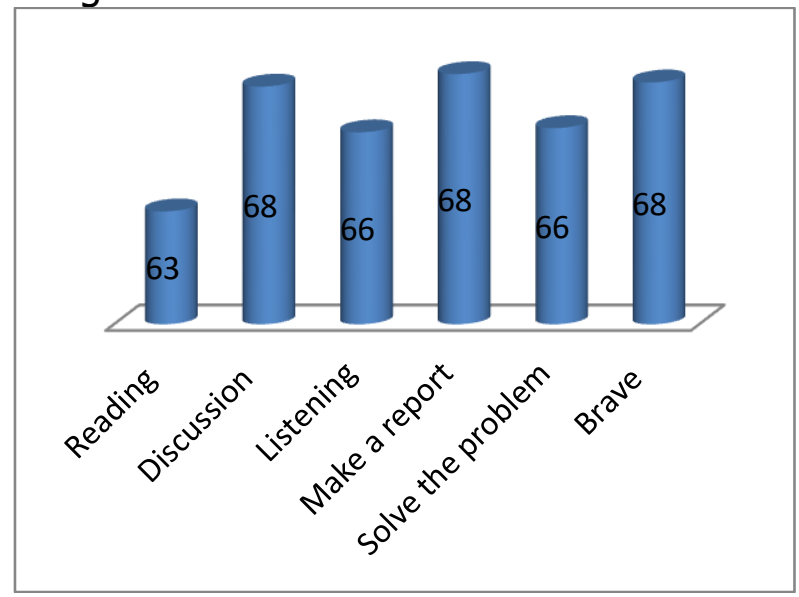

Figure 2. Student learning activities cycle II

Based on the figure 2 it can be concluded that from the 6 indicators of student learning activities, the average student score is 66 . This student learning activity as a whole is good. Whereas for each student there needs to be an increase in learning activities.

Learning in the first cycle can be done as planned. In general, students feel motivated even though are not optimal, especially the carrier of learning perseverance. In the first cycle of several activities students have followed the learning well except for bravery, because students do not have the bravery to issue their opinions. Students feel insecure for fear of being wrong if they express opinions and will be laughed at by their friends. In addition to the discussion activities that are also not optimal, this is 
because students do not have an understanding of the mastery of the material so that they carry out discussion activities are not spirited and not serious in the group.

Seeing the results found, so the researcher needs to improve about the accuracy of students entering the class by telling students not to be late again at the next meeting. The teacher must add to the giving of words of praise and give rewards to students, so students are motivated again to listen to the material delivered by the teacher seriously. As for of The form of praise given to students who actively participated in group discussions is very good because they have been active in group discussions. or a good report, in addition to giving value also words good. Giving bonus prizes extra value to students who collect on time. Whereas for imperfect reports written words, please read to more increased. To improve student learning activities the teacher must make small notes on the board so students have their own notes and do not copy the notes of other friends. So it is hoped that if students have recorded their own notes they will have an understanding of the material and be able and courageous in expressing opinions in discussions.

\section{Cycle II}

Planning activity carried out in cycle II is the same as planning in the previous cycle I. Based on the results of the reflection of this planning stage will discuss how to solve the problems that exist in the first cycle, while the weaknesses found during the first cycle are minimized. From reflection in cycle I, the teacher prepares actions to be carried out in cycle II. From the weaknesses of the first cycle that has been described in the reflection of the first cycle, the teacher seeks to increase motivation to learn, the teacher will give praise and rewards to students, so students are motivated again to listen to the material delivered by the teacher seriously.

For students who prepare on time for their projects, bonus prizes will be awarded to students who collect on time. For students who are late the teacher will provide sanctions such as erasing the blackboard or tidying the table of friends who have not been neat before learning is carried out. The teacher also provides reinforcement, motivates students and direction so that students are more active during the learning process, even though there is a learning time that is carried out at noon after physical education.

Meanwhile, to improve student learning activities in cycle II the teacher will have to make small notes on the board so students have their own notes and do not copy the notes of other friends. the hope in the cycle II students are bolder in expressing their opinions. The learning process gives results to students reasoning abilities, where an average achievement of 82.16 is obtained. For more clearly can be seen in figure 3: 


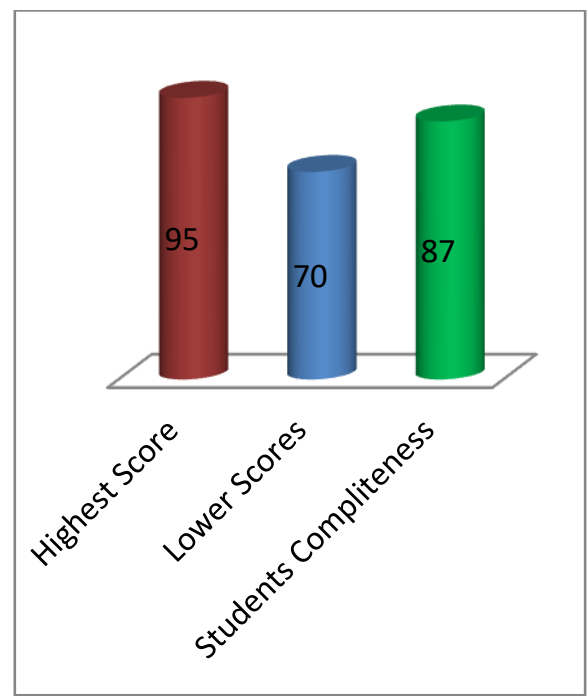

Figure 3. Results of obtaining reasoning ability of students in cycle II.

Based on figure it can be concluded that in cycle II the reasoning ability of students has increased from cycle I and is above the expected completeness criteria. In addition, student learning activities have also increased with the application of problem solving learning models. For more details can be seen in figure 4:
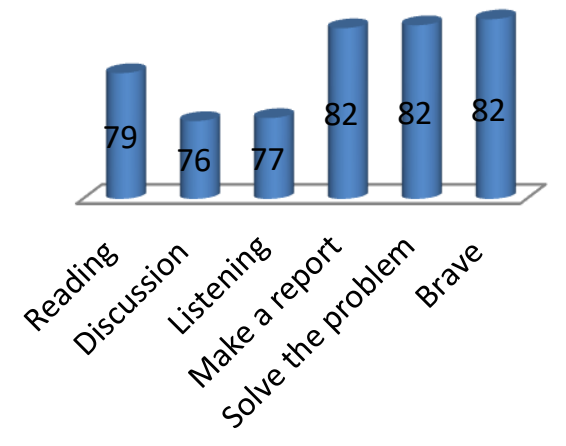

Figure 4. Student Learning Activities Cycle II
Learning in this cycle has been carried out in accordance with the plan. In the cycle II of learning activities students have followed the learning well except about bravery. Based on the results of the distribution of questionnaires distributed in class $\mathrm{V}$ and observations made by teachers the courage of students is still low, this is because there are students who are not yet confident in issuing opinions. Students doubt to express opinion even though they know the answers to the material discussed. Learning methods that are often carried out conventionally also affect students, because teachers rarely use the method of discussion students are not trained to issue opinions.

Seeing from the results that researchers found in the field, it is necessary to have improvements to be made to students so they are accustomed to discipline so that the work done can provide maximum results. The teacher must familiarize the learning method with group discussion so that students are accustomed to expressing their opinions and accustomed to always being brave.

\section{DISCUSSION}

In this current era, innovations that can be carried out by teachers are needed. The mastery of technology education is currently an important key in facing future challenges (Fitria, 2014). During the implementation of learning activities the teacher has applied the problem solving method so that students 
are able to develop their reasoning activities in solving math problems. Students' reasoning has increased from the class action cycle I to the end of the cycle III meeting. So that student reasoning during learning before taking action until the end of the action has increased significantly. It can be concluded that solving mathematics using problem solving methods can improve student reasoning. In addition students are also required to ask a lot of questions and must be able to develop the ability to think in solving a problem, with this activity the students themselves are trained to think scientifically. Students are required to be able to explain the completion process. The statement was supported from research conducted by Al-Badri (2012) by learning problem solving, students can develop ways of thinking, habits, perseverance and curiosity as well as confidence in unusual situations, which will serve them well outside the classroom mathematics. This is also in line with research conducted by Fitria (2017b: 41) which explains that student learning outcomes can be seen from the ability of students to remember the learning that has been delivered by the teacher during the learning process and how these students can apply it in daily life.

Learning with problem solving models can also improve learning activities of fifth class students. This can also be seen from the activities of students who are relevant to learning activities with indicators that have been compiled and measured during learning (Gustina,
Syahrilfuddin, Noviana, 2019). The relevant student activities when learning takes place are students able to read, students can carry out discussions, students can listen, students can make reports and students are able to solve problems well.

The success of this student activity can be seen from the change in attitudes and behaviour of students and students thoughts during the learning process. This explanation is in line with the opinions expressed by Rosalia (2005:4) and Lestari et al. (2019) student of the active during learning takes place is one of the successes, desires and motivations of students to learn, where a student is said to be active if students have characteristics including actively asking the teacher, or to other students, want to do the assignments given by the teacher, able to answer every question, happy to be given a learning assignment.

\section{CONCLUSSION}

Based on the results of research and discussion it can be concluded that the application of problem solving learning models to solve mathematical problems can improve students' mathematical reasoning and learning activities because students' learning is guided to be able to write down the steps used to solve math problems.

\section{REFERENCES}

Al-Badri, S. (2012). Statistical Methods for Quantitative Research. Yogyakarta: Penerbit Ombak.

Anastasha D., Fitria, Y., \& Irdamurni, I. 
(2018). The Effect Of Inquiry Learning Toward 5th Grade Students' Understanding On Sciences Based On Motivation In Padang. Jurnal Aplikasi IPTEK Indonesia, 1-5.

Depdiknas. (2006). Permendiknas No 22 Tahun 2006 tentang standar isi. Jakarta.

Eggen, P. D. K. (2012). Learning Strategies and Models. Jakarta: PT. Indeks.

Fauzan, A., \& Yerizon. (2013). The Effect of the RME Approach and Learning Independence on Student Mathematical Ability. Prosiding Semirata FMIPA Universitas Lampung

Fitria, Y. (2014). Reflection on Mapping of Understanding of Elemantary School Teacher About Integrated Science Learning. PEDAGOGI: Scientific Journal of Educational Sciences, 14(2)

Fitria, Y. (2017a). Development of ProblemBased Teaching Materials for the Fifth Class of Elementary School. TA'DIB, 20(2), 99-106.

Fitria, Y. (2017b). Effectiveness of Student Learning Competency Achievements in Learning Science in Primary Schools. Journal of Educational Innovation and Elementary School Learning. Jurnal Inovasi Pendidikan dan Pembelajaran Sekolah Dasar, 1(2), 34-42.

Fitria, Y., Permanasari, A., Sudargo, F., \& Sopandi W. (2013). Elementary Teacher Student Perspective to Natural Science Learning as Accomodate Effort of Need Study Capability. International Journal of Science and Research, 2(3), 482-485.

Gustina, H. T., Syahrilfuddin, S., \& Noviana, E. (2019). Pengaruh Pendekatan PEndidikan Matematika Realistik Indonesia (PMRI) terhadap Hasil
Belajar Matematika Siswa Kelas III SD Negeri 144 Pekanbaru. Tunjuk Ajar: Jurnal Penelitian IImu Pendidikan, 2(1), 30-39.

Muijs, D., \& Reynolds, D. (2008). Effective Teaching. Yogyakarta: Pustaka Belaja.

Mulyati., Firman., \& Fitria, Y. (2016). The Effectiveness of Mathematics Learning With Problem Based Learning Approach and Motivation Against Student Learning Outcomes Class V Primary Schools 113 in Pekanbaru.

Murtiani, M., Fauzan, A., \& Ratnawulan, R. (2012). Application of Lesson StudyBased Contextual Teaching And Learning (CTL) Approach in Improving the Quality of Physics Learning in SMP Negeri Kota Padang. Jurnal Penelitian dan Pembelajaran Fisika, 1(1), 1-21.

Oktriani W, Fauzan, A., \& Ellizar. (2018). Increased activity and critical thinking ability of learners through cooperative learning model type numbered heads together aided by media quipper school in class X Multimedia SMK. Proceeding of International Conferences on Education, Social Sciences and Technology DOI: https://doi.org/10.29210/20181145.

Lestari, S., Syahrilfuddin, S., Putra, Z. H., \& Hermita, N. (2020). The effect of realistic mathematic approach on students' learning motivation. Journal of Teaching and Learning in Elementary Education, 2(2), 145-156.

Putra, Y., Zulkardi, Z., \& Hartono, Y. (2016).Development of PISA Mathematical Model Levels 4, 5, 6 Using Context Lampung. Kreano, Journal of Creative-Innovative Mathematics, 71$), 10-16$.

Rosalia. (2005). Learning activity. Jakarta: 
PT Rineka Cipta.

Rusman. (2010). Learning Models: Developing Teacher Professionalism, Second Edition. Jakarta: Raja Grafindo Persada.

Sardiman, A. M. (1986). Interaction and Motivation for Learning and Teaching. Jakarta: Raja. Grafindo Persada.

Sari, F. K., Rakimahwati, R., \& Fitria, Y. (2019). Relationship between Interest and Student Learning Outcomes in Mathematics Learning for Class VI Elementary School Jati Tanah Tinggi. Jurnal Basicedu, 3 (2), 397-405.

Widjaja, W., Dolk, M., \& Fauzan, A. (2020). The Role of Contexts and Teacher's Questioning to Enhance Students' Thinking. Journal of Science and Mathematics in Southeast Asia, 33(2), 168-186.

Wina, S. (2008). Learning System Planning \& Design. Jakarta: Kencana. 